\title{
IN-SITU SYNTHESIS OF TITANIUM CARBIDE PARTICLES IN AN IRON MATRIX DURING DIODE-LASER SURFACE ALLOYING OF DUCTILE CAST IRON
}

\author{
IN SITU SINTEZA DELCEV TITANOVEGA KARBIDA V OSNOVI \\ ŽELEZA MED POVRŠINSKIM LEGIRANJEM LITEGA ŽELEZA Z \\ DIODNIM LASERJEM
}

\author{
Damian Janicki \\ Silesian University of Technology, Faculty of Mechanical Engineering, Welding Department, 18a Konarskiego Street, \\ 44-100 Gliwice, Poland \\ damian.janicki@polsl.pl
}

Prejem rokopisa - received: 2015-07-02; sprejem za objavo - accepted for publication: 2016-05-03

doi:10.17222/mit.2015.198

\begin{abstract}
An in-situ formation of titanium carbide ( $\mathrm{TiC})$ particles in an iron matrix during diode-laser surface alloying of ductile cast iron (DCI) with direct injection of titanium powder into a molten pool was investigated. The microstructure of the in-situ TiC-reinforced surface alloying layers (SALs) was assessed with scanning electron microscopy (SEM), energy-dispersive spectroscopy (EDS) and X-ray diffraction (XRD). Comparative erosion tests of the as-received DCI and the SALs were performed following the ASTM G 76 standard test method. It was found that the morphology and volume fraction of the TiC particles directly depend on the amount of the titanium powder introduced into the molten pool, which, in turn, is strongly affected by the laser-power level. An increase in the titanium concentration in the molten pool results in a change in the TiC morphology, form cubic ( $>2 \mu \mathrm{m}$ in size) to dendritic (up to $10 \mu \mathrm{m}$ in size). The maximum volume fraction of the TiC particles in the SALs was $12 \%$. The SALs exhibited a noticeable increase in the erosion resistance in comparison to the as-received DCI, especially at steep angles.

Keywords: in-situ composite, composite surface layer, TiC, laser surface alloying, ductile cast iron, erosive wear
\end{abstract}

Preiskovan je bil in situ nastanek delcev titanovega karbida (TiC) v osnovi železa med legiranjem površine duktilnega litega čeleza (DCI) z diodnim laserjem, z vpihovanjem titanovega prahu v staljeno kopel. Mikrostruktura površinskega legiranega sloja (SAL), ojačanega $\mathrm{z}$ in situ nastalim TiC je bila ocenjena $\mathrm{z}$ vrstičnim elektronskim mikroskopom (SEM), $\mathrm{z}$ energijsko disperzijsko spektroskopijo (EDS) in z rentgensko difrakcijo (XRD). Primerjalni erozijski preizkusi med dobavljenim DCI in SAL so bili izvedeni po ASTM G 76 standardni preizkusni metodi. Ugotovljeno je, da sta morfologija in volumski delež TiC delcev neposredno odvisna od količine prahu titana, ki je doveden v talino, kar je posledično močno odvisno od moči laserja. Povečanje koncentracije titana $\mathrm{v}$ staljeni kopeli se odraža na spremembi morfologije TiC iz kubične (pri velikosti $>2 \mu \mathrm{m}) \mathrm{v}$ dendritno (do velikosti $10 \mu \mathrm{m}$ ). Največji volumski delež delcev TiC v SAL je bil $12 \%$. SAL je pokazal občutno povečanje odpornosti na erozijo v primerjavi z dobavljenim DCI, še posebno pri večjih kotih.

Ključne besede: in situ kompozit, kompozitna površinska plast. TiC, legiranje površine z laserjem, duktilno lito železo, erozijska obraba

\section{INTRODUCTION}

Ductile cast iron (DCI) is extensively used for manufacturing machine parts in many industries such as automotive, power generation, mining, military and agricultural industry. ${ }^{1,2}$ However, in some applications, there is a need to increase the durability of machine parts by improving their resistance to erosion. ${ }^{3-7}$ The enhancement of erosion resistance of DCI can be achieved by reinforcing its surface layer with ceramic particles (the reinforcing phase), in particular, with an in-situ synthesis of titanium carbide (TiC). During the in-situ fabrication of composite surface layers (CSLs), reinforcing phases (RPs) are formed throughout the matrix (from the melt) due to a chemical reaction. ${ }^{8}$ As a result, the RPs are free of contaminants and have a high coherency and a strong interface with the metal matrix. The difficulty with the in-situ fabrication of CSLs is related to the fact that the distribution homogeneity and the average particle size of an RP depend on the solidification conditions and the fluid flow in the molten pool, so they are difficult to control. $^{8-10}$

Laser surface alloying is particularly well suited to the needs of the in-situ fabrication of the CSLs, mainly due to an accurate control of the molten-pool solidification. ${ }^{11}$ Moreover, the molten pool generated during laser processing undergoes a rapid solidification, which provides a unique opportunity to synthesize non-equilibrium phases. ${ }^{10}$ To date, a number of studies have focused on the laser surface alloying of both grey and ductile cast irons in order to improve the wear resistance. Some studies also attempted to investigate the in-situ formation of CSLs on a cast-iron substrate. ${ }^{8,9}$ Most of the research, however, have been conducted using $\mathrm{CO}_{2}$ and various types of Nd:YAG lasers. A high-power directdiode laser (HPDDL) with a uniform intensity distri- 
Table 1: Chemical composition of the investigated ductile cast iron Tabela 1: Kemijska sestava preiskovanega duktilnega litega železa

\begin{tabular}{|c|c|c|c|c|c|c|c|c|c|c|c|}
\hline $\mathrm{C}$ & $\mathrm{Si}$ & $\mathrm{Mn}$ & $\mathrm{Cu}$ & $\mathrm{Cr}$ & $\mathrm{Ni}$ & $\mathrm{Ti}$ & $\mathrm{Al}$ & $\mathrm{Mg}$ & $\mathrm{P}$ & $\mathrm{S}$ & $\mathrm{Fe}$ \\
\hline 3.21 & 2.58 & 0.23 & 0.83 & 0.07 & 0.05 & 0.03 & 0.01 & 0.04 & 0.017 & 0.008 & bal. \\
\hline
\end{tabular}

bution over the rectangular beam spot (called a flat-top beam) is especially suited for the surface-alloying process with direct injection of alloying powder into the molten pool. In the above-mentioned surface-alloying process, the flat-top beam of HPDDL and the powder shape (the powder spot size) match the laser-beam spot result in reducing the heat input and providing a better control of the molten-pool solidification. ${ }^{12,13}$

The present study investigated an in-situ formation of TiC particles during laser surface alloying of DCI with direct injection of titanium powder into the molten pool, using a high-power direct-diode laser (HPDDL) with a rectangular laser beam spot and a uniform distribution of the laser power (the flat-top beam). This study was specifically concerned with establishing the effect of processing parameters on the precipitation morphology of $\mathrm{TiC}$ particles and its distribution throughout the iron matrix.

\section{EXPERIMENTAL PROCEDURE}

The substrate material used in this investigation was a ductile cast iron (DCI) with its chemical composition shown in Table 1. Microstructurally, the DCI consisted of graphite spheres with the average diameter of $35 \mu \mathrm{m}$ in a pearlite matrix. The substrate specimens, in the form of $10-\mathrm{mm}$ discs with a diameter of $50 \mathrm{~mm}$, were ground to a surface finish of $0.5 \mu \mathrm{m} \mathrm{R}_{\mathrm{a}}$ and cleaned with acetone prior to the alloying process. A commercially available titanium powder (99.6\% purity) having a particle size range of 45-75 $\mu \mathrm{m}$ was used as the alloying material.

The laser surface alloying (LSA) was carried out using a high-power direct-diode laser (HPDDL) RofinSinar DL020 with the maximum output power of $2.0 \mathrm{~kW}$. The rectangular HPDDL beam spot with a size of $1.8 \times$ $6.8 \mathrm{~mm}$ and a focal length of $82 \mathrm{~mm}$ was focused on the top surface of the substrate and the long beam axis was set transversely to the traverse direction $(6.8 \mathrm{~mm}$ wide). The titanium powder was injected into the molten pool using an off-axis powder injection nozzle. The powder feed-rate accuracy of the used feeder was within $1 \%$. The molten pool was protected by a shielding gas argon - at a flow rate of $10 \mathrm{~L} / \mathrm{min}$. The cylindrical shielding-gas nozzle with a diameter of $20 \mathrm{~mm}$ was set coaxially with the powder feeding nozzle.

The investigation of the LSA process was performed based on the amount of titanium powder (the powder feed rate) provided per unit length of a single-pass alloy bead (SAB) in a range of $0.0010-0.0050 \mathrm{~g} / \mathrm{mm}$. To study the impact of the laser-power level and the traverse speed on the SAB geometry, microstructure and hardness, the experiments were conducted at three laser-power levels, $1000 \mathrm{~W}, 1200 \mathrm{~W}$ and $1400 \mathrm{~W}$, and different traverse speeds, ranging from $0.1 \mathrm{~m} / \mathrm{min}$ to $0.25 \mathrm{~m} / \mathrm{min}$. The surface-alloyed layers (SALs) were produced with the multi-pass overlapping alloying with an overlap ratio of $40 \%$. The experiments were performed without preheating the substrate.

Fluorescent dry penetrant testing was used to detect cracks of the SABs and SALs. The structure and morphology of the SALs were investigated with scanning electron microscopy (SEM) and energy-dispersive spectroscopy (EDS). The volume fraction of $\mathrm{TiC}$ was measured using a Nikon NIS-Elements quantitative image analysis system. The measurements were conducted on cross-sections from under the surface and in the middle areas of the SALs, over a total area of $10 \mathrm{~mm}^{2}$ for each SAL. Geometrical parameters of the SABs were measured using an optical microscope and the Image Analyzer software. The cross-sectional microhardness distribution of the SALs was measured by means of a Wilson Wolpert 401 MVD Vickers hardness tester at a load of $200 \mathrm{~g}$ for a dwell time of $10 \mathrm{~s}$. The X-ray diffraction analysis of the as-received DCI and the SALs was conducted using a PANalytical X'Pert PRO MPD $\mathrm{X}$-ray diffractometer equipped with an $\mathrm{X}^{\prime}$ Celerator detector and a Co- $K_{\alpha}(\lambda=0.179 \mathrm{~nm})$ source. The X-ray tube was operated at $40 \mathrm{kV}$ and $30 \mathrm{~mA}$.

Erosion-resistance tests of the as-received DCI and SALs were performed at impact angles of $30^{\circ}$ and $90^{\circ}$ in accordance with standard ASTM G76-95. Angular alumina powder $\left(\mathrm{Al}_{2} \mathrm{O}_{3}\right)$ with the average particle size of $50 \mu \mathrm{m}$ was used as the abrasive material. The impact velocity of the abrasive particles was kept in a range of $30 \pm 2 \mathrm{~m} / \mathrm{s}$. The abrasive-particle flow rate and test period were $2.0 \pm 0.5 \mathrm{~g} / \mathrm{min}$ and $10 \mathrm{~min}$, respectively. After the erosive wear tests, the mass loss of the specimens was measured with an accuracy of $0.01 \mathrm{mg}$.

\section{RESULTS AND DISCUSSION}

Cross-sectional macrographs of the single-pass alloyed beads (SABs) produced at a traverse speed of 0.2 $\mathrm{m} / \mathrm{min}$, a powder feed rate of $0.0016 \mathrm{~g} / \mathrm{mm}$ and two levels of laser power are presented in Figure 1. Fusionzone cross-sectional shapes indicate that, during the investigated LSA process, the surface-tension temperature coefficient on the molten-pool surface was positive. In this case, the surface tension is highest at the center of the molten pool, producing an inward fluid flow along the surface of the molten pool. ${ }^{14}$ As a result, the SABs have a hemispherical shape in their cross-sections. Fur- 


\section{JANICKI: IN SITU SYNTHESIS OF TITANIUM CARBIDE PARTICLES IN AN IRON MATRIX DURING ...}
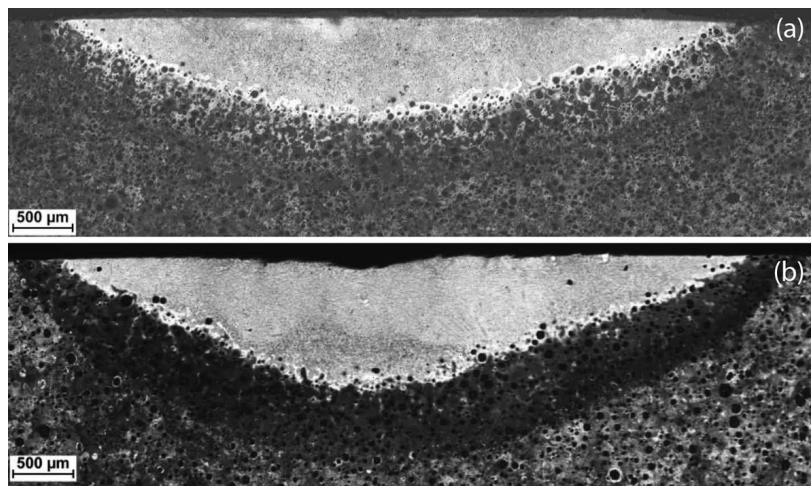

Figure 1: Macrographs of SABs produced at a traverse speed of $0.2 \mathrm{~m} / \mathrm{min}$, powder feed rate of $0.0016 \mathrm{~g} / \mathrm{mm}$ and laser-power levels of: a) $1000 \mathrm{~W}$, b) $1200 \mathrm{~W}$

Slika 1: Makroposnetek SAB-ov, nastalih pri prečni hitrosti $0,2 \mathrm{~m} / \mathrm{min}$, hitrosti dodajanja prahu $0,0016 \mathrm{~g} / \mathrm{mm}$ in pri moči laserja: a) $1000 \mathrm{~W}$, b) $1200 \mathrm{~W}$

thermore, an increase in the laser-power level, leading to a higher fluid-flow velocity in the molten pool driven by the surface-tension gradient, results in a concave bead profile and deeper fusion at the center. Typical dimensions of a SAB were a width of approx. $5.5 \mathrm{~mm}$ and a depth of fusion in a range of $0.7-1.2 \mathrm{~mm}$. The fluid-flow velocity and its pattern are also the major factors, which determine the transfer of the alloying material in the molten pool and thus directly affect the TiC distribution in the alloyed layers.

Figure 2 presents the EDS line-scan analysis made at the cross-section of a $\mathrm{SAB}$ produced at a laser power of $1400 \mathrm{~W}$, traverse speed of $0.25 \mathrm{~m} / \mathrm{min}$ and powder feed rate of $0.0042 \mathrm{~g} / \mathrm{mm}$. The composition profiles, taken at the mid-depth of the bead along the line parallel to the
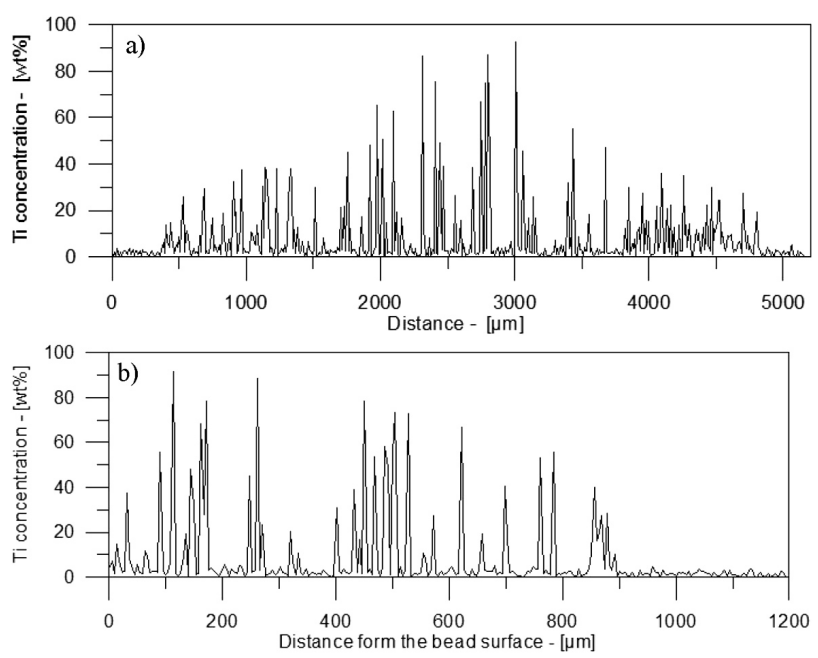

Figure 2: EDS line-scan analysis of the cross-section of a SAB produced at a laser power of $1400 \mathrm{~W}$, traverse speed of $0.25 \mathrm{~m} / \mathrm{min}$ and powder feed rate of $0.0042 \mathrm{~g} / \mathrm{mm}$ : a) profile taken at the mid-depth of the bead along the line parallel to the bead surface, $b$ ) depth profile in the centre of the bead

Slika 2: EDS-linijska analiza na preseku SAB nastalem pri laserju moči $1400 \mathrm{~W}$, prečni hitrosti $0,25 \mathrm{~m} / \mathrm{min}$ in hitrosti dodajanja prahu $0,0042 \mathrm{~g} / \mathrm{mm}$ : a) profil, posnet na srednji globini kopeli, vzdolž linije vzporedne s površino kopeli, b) profil v globino na sredini kopeli
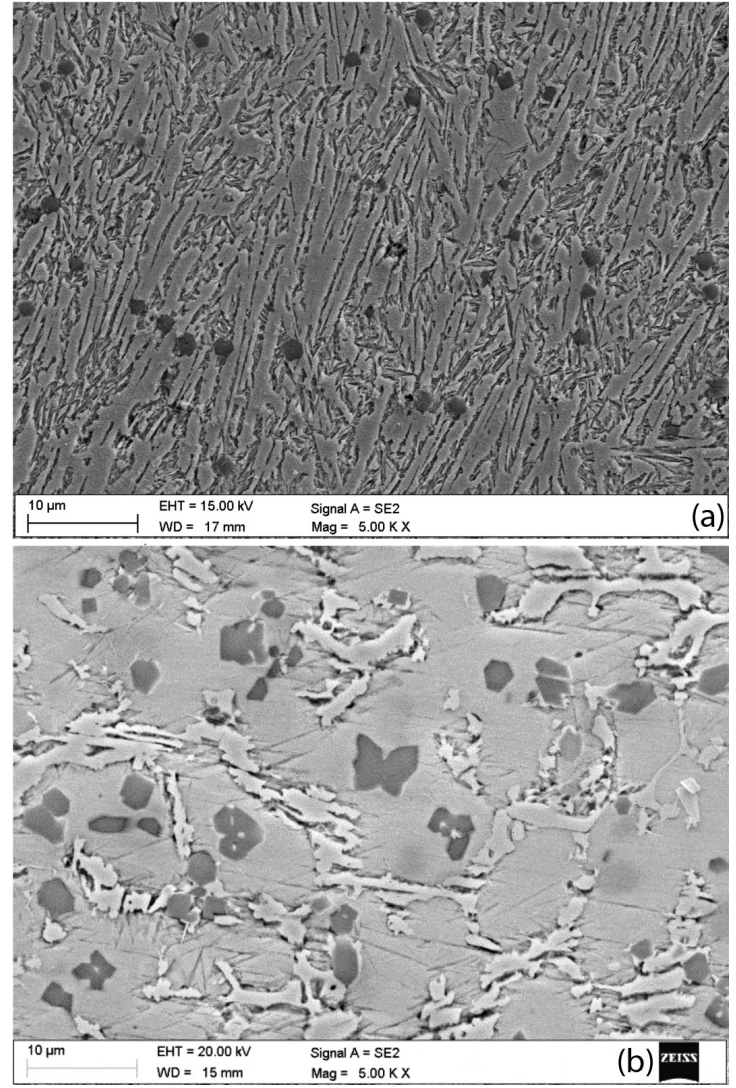

Figure: 3: SEM micrographs taken at the mid-sections of the SALs produced at a laser power of $1400 \mathrm{~W}$, traverse speed of $0.15 \mathrm{~m} / \mathrm{min}$ and powder feed rates of: a) $0.0010 \mathrm{~g} / \mathrm{mm}$, b) $0.0046 \mathrm{~g} / \mathrm{mm}$

Slika 3: SEM-posnetek iz sredine preseka SAL, nastalega pri moči laserja $1400 \mathrm{~W}$, prečni hitrosti $0,15 \mathrm{~m} / \mathrm{min}$ in hitrosti dodajanja prahu: a) $0,0010 \mathrm{~g} / \mathrm{mm}$, b) $0,0046 \mathrm{~g} / \mathrm{mm}$

bead surface (Figure 2a), indicated a slight titanium (Ti) enrichment in the centre of the alloyed bead, whereas the depth profile revealed an almost homogeneous distribution of $\mathrm{Ti}$ (Figure 2b). It follows that this fluid-flow pattern transfers the alloying elements quite efficiently throughout the fusion zone, leading only to a slightly

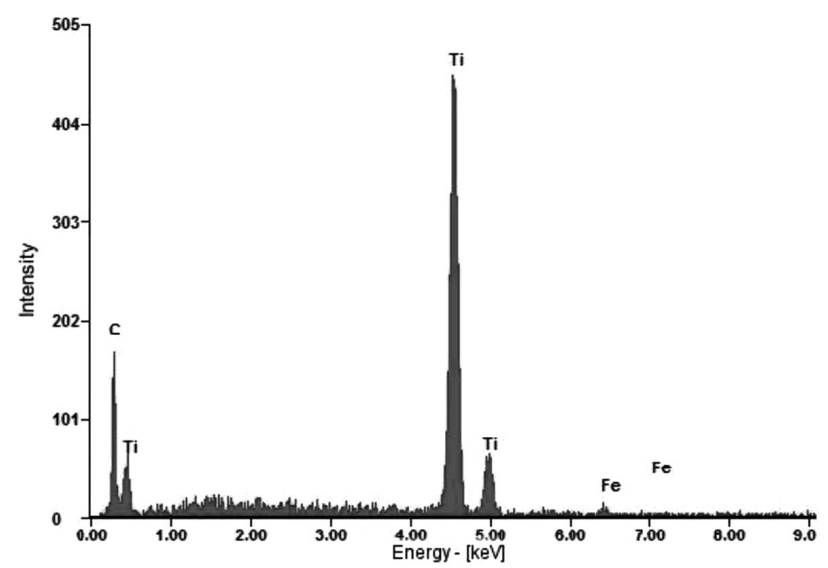

Figure 4: Typical EDS spectrum of a TiC particle Slika 4: Značilen EDS-spekter delcev TiC 
D. JANICKI: IN SITU SYNTHESIS OF TITANIUM CARBIDE PARTICLES IN AN IRON MATRIX DURING ...

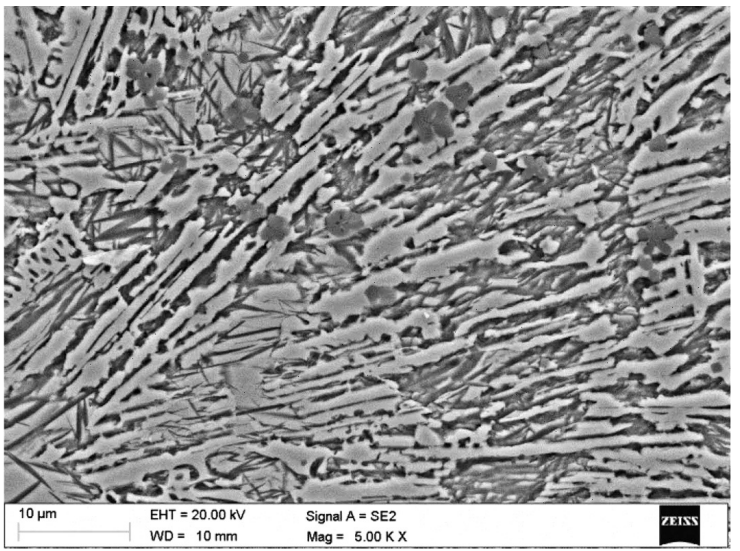

Figure 5: SEM micrograph of the fusion boundary area of a SAL produced at a laser power of $1400 \mathrm{~W}$, traverse speed of $0.15 \mathrm{~m} / \mathrm{min}$ and powder feed rate of $0.0046 \mathrm{~g} / \mathrm{mm}$

Slika 5: SEM-posnetek meje zlivanja področja SAL, nastalega pri laserju moči $1400 \mathrm{~W}$, prečni hitrosti $0,15 \mathrm{~m} / \mathrm{min}$ in hitrosti dodajanja prahu $0,0046 \mathrm{~g} / \mathrm{mm}$

higher fraction of the $\mathrm{TiC}$ precipitation in the central area of the alloyed bead.

Generally, the laser-power level determines the maximum amount of titanium powder that can be introduced to a $\mathrm{SAB}$, thus the concentration of titanium in the molten pool and, in consequence, the morphology and fraction of TiC particles. In the cases of laser-power levels of 1000 and $1400 \mathrm{~W}$, the maximum powder feed rate, which allows the production of SABs with no internal defects, such as porosity or microvoids, was 0.0016 and 0.0046 $\mathrm{g} / \mathrm{mm}$, respectively.

Figure 3 shows SEM micrographs of the surface alloyed layers (SALs) produced at powder feed rates of 0.0010 and $0.0046 \mathrm{~g} / \mathrm{mm}$. Based on the EDS analysis, the approximate concentration of Ti in these SALs was estimated to be $3 \%$ and $7 \%$ of the mass fractions, respectively. In turn, a quantitative analysis of the micrographs of the above-mentioned SALs indicated that the volume fraction of the TiC particles was approx. $4 \%$ and $12 \%$, respectively.

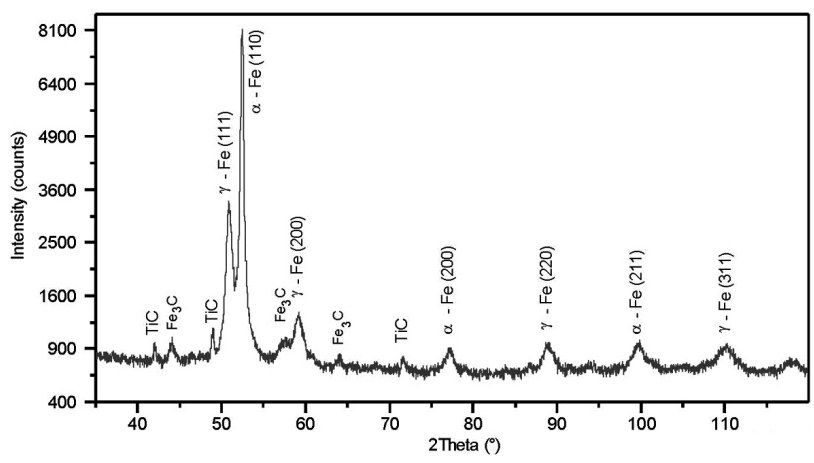

Figure: 6: XRD pattern of a SAL produced at a laser power of 1400 $\mathrm{W}$, traverse speed of $0.15 \mathrm{~m} / \mathrm{min}$ and powder feed rate of $0.0046 \mathrm{~g} / \mathrm{mm}$ Slika 6: Rentgenogram SAL, nastalega pri laserju moči $1400 \mathrm{~W}$, prečni hitrosti $0,15 \mathrm{~m} / \mathrm{min}$ in hitrosti dodajanja prahu $0,0046 \mathrm{~g} / \mathrm{min}$

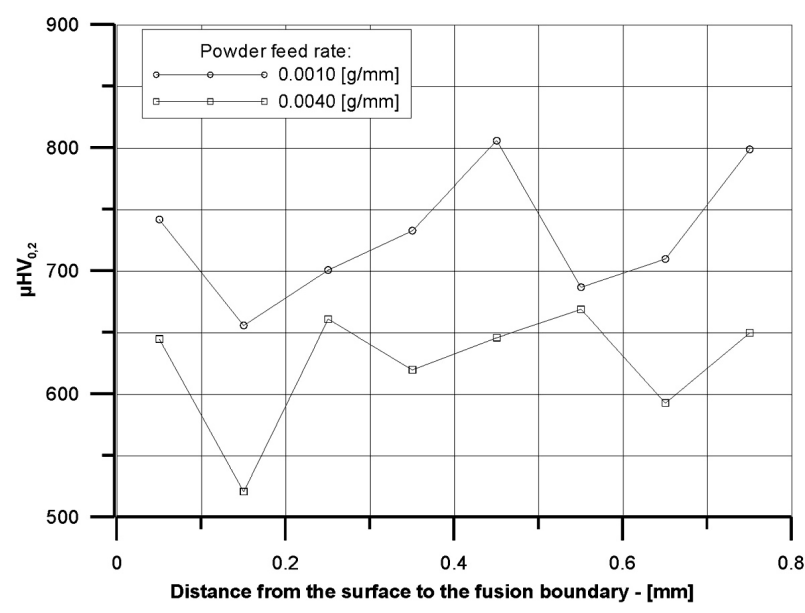

Figure 7: Microhardness distribution on the cross-sections of the SALs produced at a laser power of $1400 \mathrm{~W}$, traverse speed of $0.2 \mathrm{~m} / \mathrm{min}$ and different powder feed rates

Slika 7: Razporeditev mikrotrdote na preseku SAL, nastalega pri moči laserja $1400 \mathrm{~W}$, prečni hitrosti $0,2 \mathrm{~m} / \mathrm{min}$ in pri različni hitrosti dodajanja prahu

Figure 4 presents a typical EDS spectrum of the TiC particles (dark grey particles). As can be seen in Figure 3, the concentration of Ti strongly affects the shape and size of TiC particles. With an increasing Ti concentration, the morphology of $\mathrm{TiC}$ changes form cubic (>2 $\mu \mathrm{m}$ in size) to dendritic (up to $10 \mu \mathrm{m}$ in size). Furthermore, the size of the $\mathrm{TiC}$ particles varies from the fusion boundary to the surface of a SAL, due to the changes in the local solidification conditions. The smaller TiC particles observed in the fusion boundary area (Figure 5) result primarily from the highest cooling rate; however, as indicated by the EDS line-scan analysis (Figure 2b), they can also be attributed to a lower concentration of $\mathrm{Ti}$ in this area.

The presence of TiC particles in the SALs was confirmed with the X-ray diffraction analysis (Figure 6). The X-ray diffraction pattern of a SAL, containing the highest volume fraction of $\mathrm{TiC}$, indicated that martensite is the dominant phase. Apart from martensite, austenite and cementite were also detected. Furthermore, a metallographic examination and X-ray analysis revealed that an increasing titanium concentration in the SALs increases both the volume fractions of $\mathrm{TiC}$ and austenite, leading simultaneously to a lower fraction of cementite. All the SALs were free of porosity and microcracks.

The results of fluorescent dry penetrant testing showed that the SABs were free of cracks; however, transverse cracks were revealed in all the SALs. The cracks propagate mainly perpendicularly to the fusion boundary and do not affect the integrity of the SALs.

Figure 7 shows the microhardness distribution on the cross-sections of the SALs produced at a laser power of $1400 \mathrm{~W}$, traverse speed of $0.2 \mathrm{~m} / \mathrm{min}$ and different powder feed rates. As can be seen, the increase in the powder feed rate slightly reduced the hardness of the SAL, 


\section{JANICKI: IN SITU SYNTHESIS OF TITANIUM CARBIDE PARTICLES IN AN IRON MATRIX DURING ...}

which is connected with the above-mentioned change in the volume fractions of austenite and cementite.

The solid-particle erosion-test results showed that the HPDD laser surface alloying of DCI, involving an in-situ synthesis of $\mathrm{TiC}$, provides a significant improvement in the erosion resistance of the investigated DCI for both $30^{\circ}$ and $90^{\circ}$ impact angles. Erosion values of the SALs at an impact angle of $90^{\circ}$ were approx. $40 \%$ lower than those of the as-received DCI. In turn, for the impact angle of $30^{\circ}$, the SALs exhibited a three-time higher erosion resistance than for the as-received DCI. A detailed analysis of the erosion-degradation mechanism of the investigated in-situ composite layers is still in progress.

\section{CONCLUSIONS}

The HPDD laser surface alloying of DCI with direct injection of the titanium powder into the molten pool enables us to produce in-situ TiC-reinforced surface alloying layers with quite a uniform distribution of $\mathrm{TiC}$ throughout the matrix and the $\mathrm{TiC}$ volume fraction of up to $12 \%$. The morphology and fraction of $\mathrm{TiC}$ particles depend directly on the amount of the titanium powder introduced into the molten pool, which, in turn, is strongly affected by the laser-power level. With an increasing titanium (Ti) concentration in the molten pool, the morphology of the TiC particles changes form cubic (> $2 \mu \mathrm{m}$ in size) to dendritic (up to $10 \mu \mathrm{m}$ in size). Moreover, the increase in the $\mathrm{Ti}$ concentration increases the volume fraction of both $\mathrm{TiC}$ and austenite and, simultaneously, results in a lower fraction of cementite. The SALs exhibited a noticeable increase in the erosion resistance in comparison to the as-received DCI, especially at steep angles.

\section{REFERENCES}

${ }^{1}$ R. Elliott, Cast Iron Technology, Butterworth-Heinemann, 1988
${ }^{2}$ R. Burdzik, Ł. Konieczny, Z. Stanik, P. Folega, A. Smalcerz, A. Lisiecki, Analysis of impact of chosen parameters on the wear of camshaft, Archives of Metallurgy and Materials, 59 (2014) 3, 957-963, doi:10.2478/amm-2014-0161

${ }^{3}$ C. H. Chen, C. J. Altstetter, J. M. Rigsbee, Laser processing of cast iron for enhanced erosion resistance, Metallurgical Transactions A, 15A (1984), 719-728

${ }^{4}$ J. H. Abbud, Microstructure and erosion resistance enhancement of nodular cast iron modified by tungsten inert gas, Materials and Design, 35 (2012), 677-684, doi:10.1016/j.matdes.2011.09.029

${ }^{5}$ K. F. Alabeedi, J. H. Abboud, K. Y. Bnounis, Microstructure and erosion resistance enhancement of nodular cast iron by laser melting, Wear, 266 (2009), 925-933, doi:10.1016/j.wear.2008.12.015

${ }^{6}$ A. Kurc-Lisiecka, W. Ozgowicz, W. Ratuszek, J. Kowalska, Analysis of Deformation Texture in AISI 304 Steel Sheets, Solid State Phenomena, 203-204 (2013), 105-110, doi:10.4028/www.scientific.net/ SSP.203-204.105

${ }^{7}$ M. Staszuk, L. A. Dobrzanski, T. Tanski, W. Kwasny, M. Musztyfaga-Staszuk, The effect of PVD and CVD coating structures on the durability of sintered cutting edges, Archives of Metallurgy and Materials, 59 (2014), 269-274, doi:10.2478/amm-2014-0044

${ }^{8}$ H. I. Park, K. Nakata, S. Tomida, In situ formation of TiC particles composite layer on cast iron by laser alloying of thermal sprayed titanium coating, Journal of Materials Science, 35 (2000) 747-755, doi:10.1023/A:1004717603612

${ }^{9}$ K. Das, T. K. Bandyopadhyay, S. Das, A Review on the various synthesis routes of $\mathrm{TiC}$ reinforced ferrous based composites, Journal of Material Science, 37 (2002), 3881-3892, doi:10.1023/ A:1019699205003

${ }^{10}$ A. Singh, N. B. Dahotre, Phase evolution during laser in-situ carbide coating, Metallurgical and Materials Transactions A, 36A (2005), 797-803, doi:10.1007/s11661-005-1010-6

${ }^{11}$ A. Lisiecki, Welding of thermomechanically rolled fine-grain steel by different types of lasers, Archives of Metallurgy and Materials, 59 (2014) 4, 1625-1631, doi:10.2478/amm-2014-027

${ }^{12}$ D. M. Janicki, High power diode laser cladding of wear resistant metal matrix composite coatings, Solid State Phenomena, 199 (2012), 587-594, doi:10.4028/www.scientific.net/SSP.199.587

${ }^{13}$ A. Lisiecki, Titanium matrix composite Ti/TiN produced by diode laser gas nitriding, Metals, 5 (2015), 54-69, doi:10.3390/ met5010054

${ }^{14}$ C. R. Heiple, J. R. Rop, R. T. Stanger, J. Aden, Surface active element effect on the shape of GTA, Laser and electron beam welds, Welding Journal, 62 (1983), 72-77 